DOI:10.22337/2587-9618-2019-15-2-65-71

\title{
ADHESION OF COMPONENTS OF COMPOSITE STEEL AND CONCRETE CROSS SECTION IN ANALYSIS OF BEAMS WITH CONCRETE ENCASED SECTIONS
}

\author{
Alexey S. Krylov \\ JSC Research Center of Construction, Moscow, RUSSIA
}

\begin{abstract}
A brief overview of the issues of aggregate work of components of the composite steel and concrete section is made. It is presented various options for the layout of the cross-section of beams used in the practice of design. A review of the design of the regulatory documents regarding the issues of adhesion of cross-section elements is performed. The characteristic of experimental models is given. The features of destruction of models are shown. The reasons of the destruction are analyzed. The case of the loss of the bearing capacity of the element due to relaxation (loss) of adhesion at the steel - concrete interaction boundary is considered. Various shear surfaces of the concrete section are given. Calculations of the bearing capacity of the composite steel - concrete beams for each computational surface were performed, the obtained results were evaluated. Conclusions have been made on the question of ensuring aggregate work in case of composite steel - concrete beams with a fully encased steel core.
\end{abstract}

Keywords: concrete, steel, reinforced concrete, composite steel and concrete structure, shear, adhesion, stud

\section{УЧЕТ СЦЕПЛЕНИЯ КОМПОНЕНТОВ СТАЛЕЖЕЛЕЗОБЕТОННОГО СЕЧЕНИЯ В РАСЧЕТАХ БАЛОК С ПОЛНОСТЫЮ ОБЕТОНИРОВАННЫМ СТАЛЬНЫМ СЕРДЕЧНИКОМ}

\author{
А.С. Крылов \\ Научно-исследовательский центр «Строительство», г. Москва, РОССИЯ
}

\begin{abstract}
Аннотация: Выполнен краткий обзор вопросов совместной работы компонентов сталежелезобетонного сечения. Представлены различные варианты компоновки поперечного сечения балок, используемые в практике современного проектирования. Выполнен обзор расчетных положений нормативных документов касательно вопросов сцепления элементов поперечного сечения. Дана характеристика экспериментальных моделей. Приведены общие картины разрушения моделей, проанализированы причины разрушения. Рассмотрен вариант потери несущей способности элемента в следствии ухудшения (потери) сцепления на границе сталь-бетон. Приведены различные поверхности среза бетонной части сечения. Выполнены расчеты несущей способности сталежелезобетонных балок для каждой расчетной поверхности, дана оценка полученных результатов. Сделаны выводы по вопросу обеспечения совместной работы применительно к случаю сталежелезобетонных балок с полностью обетонированным стальным сердечником.
\end{abstract}

Ключевые слова: бетон, сталь, железобетон, сталежелезобетонная конструкция, сдвиг, сцепление, анкерное устройство

The late XX - early XXI centuries were marked by the extensive introduction of steel-concrete structures into building practice, the main types of which are columns and beams with stiff reinforcement. The significant development of highrise construction required an increase in the bearing capacity of structural elements and at the same time a reduction in their dimensions. The columns made of the composite steelconcrete ensure these requirements [1]. The development of transport networks and an increase in the carrying capacity of transport lead to the 
widespread use of composite steel - concrete structure in bridge construction. Majority of modern transport overpasses and bridge junctions are implemented using composite steelconcrete structure (beams), where a common design consideration is the combination of steel beams with a slab of concrete along top flange (Figure 1) [2]. Composite steel - concrete beams with a fully encased steel core also find appliance [3], as it is shown in Figure 2.

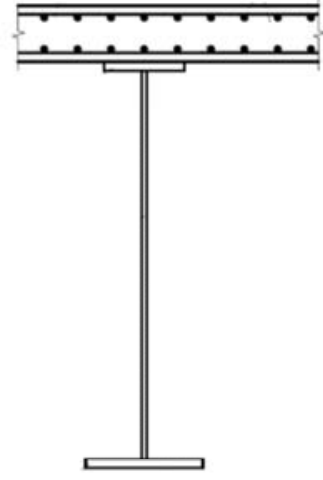

a) slab without thickening

Figure 1. Example of composite steel-concrete beam - steel I-beam with reinforced concrete slab along top flange.

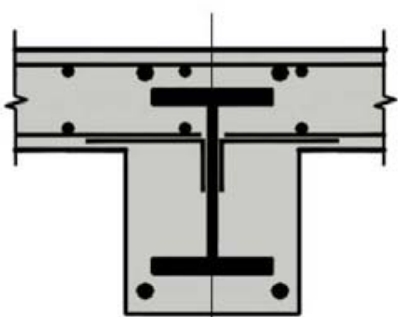

Figure 2. Example of composite steel - concrete beam with a fully encased steel core.

The issues of adhesion of a reinforced concrete slab with a steel beam, as well as the effect of various anchors (flexible, rigid connectors) on the bearing capacity of the composite reinforced concrete elements are studied quite well $[2,4]$ due to it wide acceptance. The necessity of applying anchors and features of the calculation are governed by the relevant regulatory documents $[2,4,5,6]$ and recommendations [7].
The issues of adhesion with a fully encased steel section to concrete were also investigated by a number of authors [8]. Let us note that regulatory documents $[4,5]$ regulate placing of anchors for beams with rigid reinforcement (with a fully encased steel core), but the focus is on placing the stud only on the wall of a steel section (Figure 3 ).

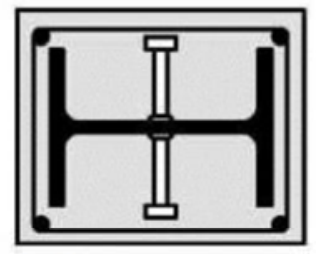

Figure 3. Installation of anchor studs on the wall of the steel profile according to [4].

The special attention is not paid to placing the studs on the shells of the I-beam (in contrast to the case of a steel non-concrete beam with a reinforced concrete slab along the upper shelf). This can be explained by the layout of the composite steel - concrete section, when rigid reinforcement is distributed fairly evenly over the entire cross section and the distance from the top shell of the I-section (Figure 3) to the edge of the beam is small. At the same time, in Eurocode 4 [4], in section 6.7.4.2, there is a note on this issue - it is necessary to check the sufficiency of web reinforcement to resist shear force for zones of the concrete part of the cross section that do not have direct contact with the steel core by anchors (Figure 4 - considered a shear along the lines A-A).

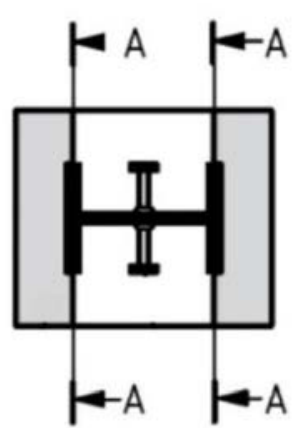

Figure 4. Checking composite steel - concrete element under shear force along line $A-A$ according to [4]. 
However, such a check is provided only for the composite steel - concrete columns in case when the load is attached either only to the steel or to the concrete part of the section. The need for such checks is not regulated for beams with rigid reinforcement and fully encased steel core, although in some cases it must be performed. Alternatively, the cross-sectional layout of beams with rigid reinforcement, when all or most of the steel core are located in the tension side, that implies a significant distance from the top shell of steel section to the edge of the cross-section (Figure 5).

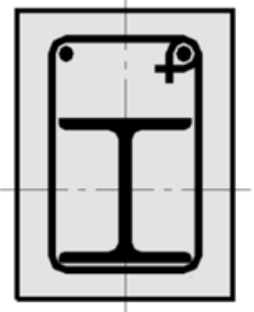

Figure 5. An example of a beam with rigid reinforcement with a non-standard arrangement of an I-beam.

In this case, in addition to strength analysis of the normal section of the element and the corresponding fracture features (chipping of compressed zone of the concrete or breakage of the tensile reinforcement), attention should be paid to the possibility of the component damage as a result of deterioration (loss) of adhesion at the steel-concrete interface and shear of the concrete part of the beam. A choice of line of shear is marked in red in Figure 6.

A series of experiments were performed to study the behavior of the composite steelconcrete beams using high-strength concrete. The described non-standard type of destruction is recorded in the process of testing, although a detailed study of damage of a similar type was not a purpose of these experiments. During the experimental studies, 9 models of composite steel-concrete beams of rectangular cross section $200 \times 150 \mathrm{~mm}$ and $1.5 \mathrm{~m}$ length were tested. The steel core is made in the form of an I-beam.

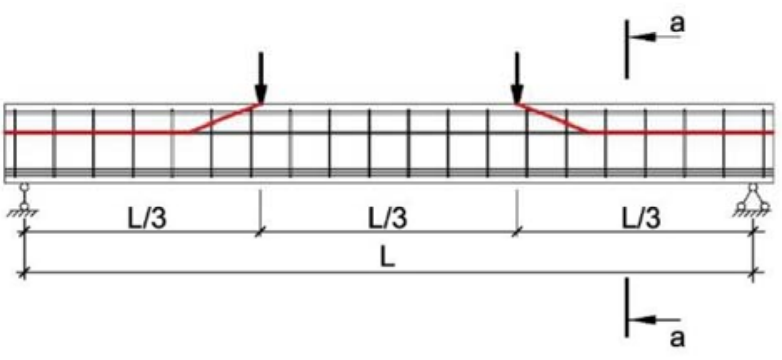

a-a

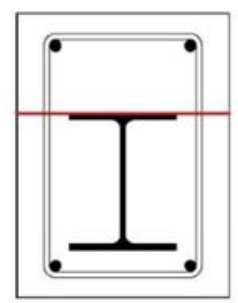

Figure 6. Possible location of the line of concrete shear at the component damage due to deterioration (loss) of adhesion at the steel-concrete interface.

The core material is $\mathrm{C} 255$ steel according to National Standard of Russian Federation GOST 27772-2015. The concrete of the models is high-strength of B75 ... B90 compressive strength class. Upper and transverse reinforcement have diameter $10 \mathrm{~mm}$ class A400 of steel 35GS. The percent of reinforcement is $7.8 \ldots$ $9.2 \%$. The beams were tested for pure bending by attaching concentrated loads in $1 / 3$ and $2 / 3$ of the span of the models. The general view of the models is shown in Figure 7. A detailed description of the experiment is given in [9].

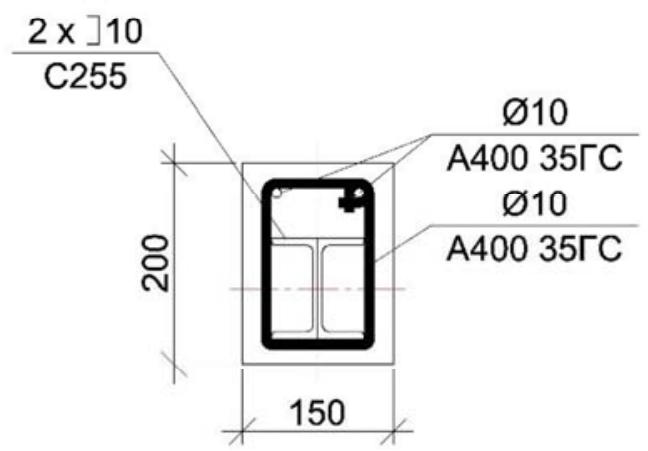

Figure 7. General view of the composite steel-concrete beam model. 

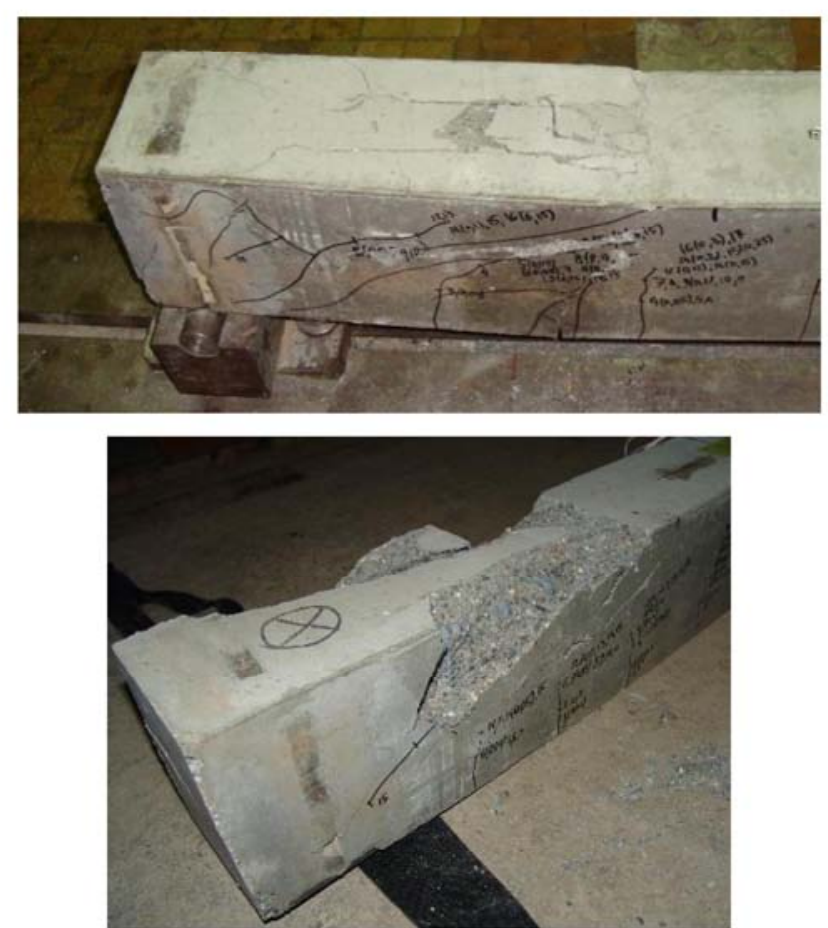

Figure 8. Characteristic destruction of models of the composite steel - concrete beams (beam fragment-extreme third part of the span).

The destruction of the models was similar and characterized by the appearance of a large number of vertical and inclined cracks, as well as horizontal cracks on the upper and lower edges of the beam. This led to partial shear of the concrete of the protection cover and uncovering of the reinforcement cage and steel core in the extreme thirds of the beam span - between the point of support and the point of attaching of the load at the last stages of loading (Figure 8). At more detailed observing of the failure models, it is supposed, that a possible reason of the destruction is a violation of the adhesion between the upper shell of the steel I-beam and concrete. In contrary to widespread destruction variant, the shear (Figure 9) occurred on the boundary of steel and concrete parts of section as it is shown in Figure 6. The destruction of a similar type is not considered in the literature before.

Theoretical calculations were performed to evaluate the obtained experimental results. The sequence of checking the shear strength of concrete along the indicated surfaces (Figure 6,9) is given below. In the presented calculations, the characteristics of materials are assumed to be equal to it actual values.

1. The height of the compressed zone of the cross section was determined and compared with the experimental value. The sequence of calculations is described in detail in regulatory documents $[5,7]$. The height of the compressed zone is $\mathrm{x}=7.0 \mathrm{~cm}$.

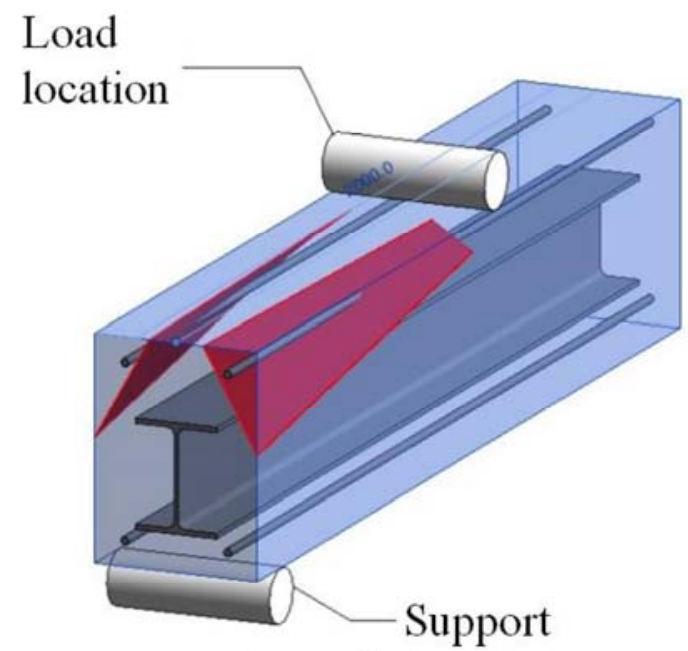

a) overall view

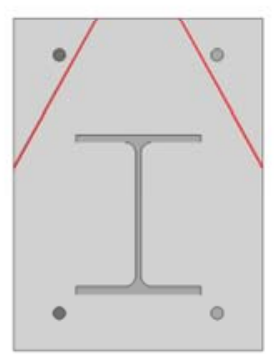

b) front view

Figure 9. Possible location of the shear surface in the concrete during the destruction of the element caused by deterioration (loss) of adhesion at the steel-concrete interface.

2 . The shearing force is determined by the formula similar (since the type of the destruction is another) (6.63) [SP 266]:

$$
S_{i}=\left(\sigma_{b 1} A_{b}+\sigma_{s 1} A_{s}\right)-\left(\sigma_{b 2} A_{b}+\sigma_{s 2} A_{s}\right),
$$

Where $\sigma_{\mathrm{b} 1}, \sigma_{\mathrm{b} 2}$ are compressive stresses in concrete in the right and left sections of the calculated part of the beam 
$\sigma_{\mathrm{s} 1}, \sigma_{\mathrm{s} 2}$ are stresses in the longitudinal reinforcement in the same sections, respectively. In the above formulas, the distance from the point of load attaching to the beam support and, respectively, the stresses $\sigma_{\mathrm{b} 2}$ и $\sigma_{\mathrm{s} 2}$ at the end of the beam is assumed to be equal to zero. Value of the shear force is:

$$
\begin{array}{r}
\mathrm{S}=\left(\mathrm{R}_{\mathrm{b}} \mathrm{bx}+\mathrm{R}_{\mathrm{sc}} \mathrm{A}_{\mathrm{sc}}^{\prime}\right)=943,9 \cdot 15,0 \cdot 7,0+ \\
4440,0 \cdot 1,57=106080 \mathrm{~kg}, \quad \text { (2) }
\end{array}
$$

where $\mathrm{R}_{\mathrm{b}}=943,9 \frac{\mathrm{kg}}{\mathrm{cm}^{2}}, \mathrm{R}_{\mathrm{sc}}=4444,0 \frac{\mathrm{kg}}{\mathrm{cm}^{2}}$

are compressive strength of concrete and reinforcement rod respectively,

$\mathrm{b}=15 \mathrm{~cm}$ is cross section width,

$x=7,0 \mathrm{~cm}$ is height of the compressed zone of the section,

$\mathrm{A}_{\mathrm{sc}}^{\prime}=1,57 \mathrm{~cm}^{2}$ is area of compressed reinforcement rod.

3. The shear strength $R_{\tau}$ of an element for various computational surfaces is calculated:

$$
R_{\tau}=A_{\tau} R_{b t}
$$

Where $A_{\tau}$ is area of the calculated shear surface, $R_{b t}$ is tension strength of concrete.

a) for the case shown in Figure 6:

$$
\begin{gathered}
\mathrm{R}_{\tau}=\left(\mathrm{l}_{1} \cdot \mathrm{l}_{2} \cdot 2\right) \cdot \mathrm{R}_{\mathrm{bt}}=(51,5 \cdot 2,9 \cdot 2) \cdot \\
68,3=20401 \mathrm{~kg},
\end{gathered}
$$

where $R_{b t}=68,3 \frac{\mathrm{kg}}{\mathrm{cm}^{2}}$,

$\mathrm{l}_{1}=51,5 \mathrm{~cm}$ is the distance from the point of load attaching to the edge of the beam (length of the shear surface),

$\mathrm{l}_{2}=2,9 \mathrm{~cm}$ is the distance from the edge of the flange of the I-beam to the edge of the cross section (width of the shear surface).

b) for the case shown in Figure 9.

Here we note that the contour of the calculated surface to determine the shear bearing capacity for concrete is accepted by the results of experimental studies. The specified computational contour accurately reflects the features of the destruction recorded during the experiments performed in this paper.

$$
\begin{aligned}
\mathrm{R}_{\tau}=\left(\mathrm{l}_{1} \cdot \mathrm{l}_{2} \cdot 2\right) \cdot \mathrm{R}_{\mathrm{bt}} & =(51,5 \cdot 14,75 \cdot 2) \cdot \\
68,3 & =103765 \mathrm{~kg},
\end{aligned}
$$

where $R_{b t}=68,3 \frac{\mathrm{kg}}{\mathrm{cm}^{2}}$

$\mathrm{l}_{1}=51,5 \mathrm{~cm}$ is the distance from the point of application of the load to the edge of the beam (length of the shear surface).

$l_{2}=14,75 \mathrm{~cm}$ is the average width of the shear surface on the test results.

The obtained value of the shear strength of the element almost completely coincided with the fracture load. The difference is $2.2 \%$.

4. A comparison of the theoretical and experimental bearing capacity of the beam, determined by the shear of concrete, is carried out. The values is quite close.

We also note that the value of the carrying capacity for shear is quite close to the bearing capacity of the element obtained in the calculation for the normal section. At the same time, the limiting state in the cross section is reached at the moment of concrete shearing along the specified calculated surfaces. The concrete stresses in the compressed zone reach the limit values, and in the tensile rigid reinforcement, the stresses correspond to the yield strength.

\section{CONCLUSIONS}

A review on the subject of combining of elements of steel-concrete structures is carried out. The features of steel-concrete beam models' destruction are analyzed for the bending tests. The destruction of the models is similar and characterized by the appearance of a large number of vertical and inclined cracks, as well as horizontal cracks. This leads to partial shear of the concrete of the protection cover and uncovering of the reinforcement cage and steel core in the extreme third of the beam span - between the point of support and the point of load attaching at the last stages of loading. The shear oc- 
curs by the surface shown in red in Figure 9, in contrast to the most common type of destruction - by the interface of steel and concrete (Figure 6 ). The damage of a similar type in the literature has not been considered previously. This type of destruction can be considered as a new type of limit state concerning to the first group of limit states (by strength).

The possible variants of the computational destruction surfaces of the composite steelconcrete beams, caused by relaxation (loss) of adhesion at the steel-concrete interface, are considered.

The surface shown in Figure 6 and, respectively, the strength value determined by formula (4) are the most dangerous cases of destruction for elements with not enough transverse reinforcement or without it. In the case of powerful transverse reinforcement, the destruction surface takes a more complex shape, that is close to the shape shown in Figure 9. In this case, the fracture load should be determined by the relationship (5).

\section{REFERENCES}

1. Travush V.I., Konin D.V., Rozhkova L.S., Krylov A.S., Kaprielov S. S., Chilin I.A., Martirosyan A.S., Fimkin A.I. Jeksperimental'nye issledovanija stalezhelezobetonnyh konstrukcij, rabotajushhih na vnecentrennoe szhatie [Experimental study of composite structures, working for eccentric compression]. // Academia. Architecture and Construction, 2016, No. 3, pp. 127-135 (in Russian).

2. SP 63.13330.2012 Mosty i truby. Aktualizirovannaja redakcija SNiP 2.05.03-84 [Bridges and culverts. The updated edition of SNiP 2.05.03-84]. Moscow, 2011 (in Russian).

3. Travush V.I., Konin D.V., Krylov A.S., Kaprielov S.S., Chilin I.A. Jeksperimental'nye issledovanija stalezhelezobetonnyh konstrukcij, rabotajushhih na izgib [Experimental study of composite struc- tures for bending elements]. // Building and Reconstruction, 2017, No. 4(72), pp. 63-71 (in Russian).

4. EN 1994-1-1 (2004) (English): Eurocode 4: Design of composite steel and concrete structures - Part 1-1: General rules and rules for buildings [Authority: The European Union Per Regulation 305/2011, Directive 98/34/EC, Directive 2004/18/EC].

5. SP 266.1325800.2016 Konstrukcii stalezhelezobetonnye. Pravila proektirovanija [Composite steel and concrete structures. Rules of design]. Moscow, 2017 (in Russian).

6. SP 63.13330.2012 Betonnye i zhelezobetonnye konstrukcii. Aktualizirovannaja redakcija SNiP 52-01-2003 [Concrete and reinforced concrete structures. The updated edition of SNiP 52-01-2003]. Moscow, 2013 (in Russian).

7. Standard of organization STO SCDA 11251254.001-018-4 Rukovodstvo po proektirovaniju stalezhelezobetonnyh konstrukcij (v razvitie SP 266.1325800.2016 "Konstrukcii stalezhelezobetonnye. Pravila proektirovanija") [Guidelines for the design of composite steel and concrete structures]. Moscow. 2018 (in Russian).

8. Travush V.I., Kaprielov S. S., Konin, D. V., Krylov A. S., Kashevarova G.G., Chilin I.A. Determination of bearing capacity for shear of the contact surface "steel - concrete" in composite steel and concrete structures for concrete of different compressive strength and fiber-reinforced concrete. // Building and reconstruction, 2016, No. 4(66), pp. 45-55 (in Russian).

9. Travush V.I., Konin D.V., Krylov A.S. Strength of composite steel and concrete beams of high-performance concrete. // Magazine of Civil Engineering, 2018, No. 3(79), pp. 36-44.

\section{СПИСОК ЛИТЕРАТУРЫ}

1. Травуш В.И., Конин Д.В., Рожкова Л.С., Крылов А.С., Каприелов С.С., 
Adhesion of Components of Composite Steel and Concrete Cross Section in Analysis of Beam with Concrete Encased Section

Чилин И.А., Мартиросян А.С., Фимкин А.И. Экспериментальные исследования сталежелезобетонных конструкций, работающих на внецентренное сжатие. // Academia. Архитектура и строительство, 2016, №3, с. 127-135.

2. СП 35.13330.2011 Мосты и трубы. Актуализированная редакция СНиП 2.05.0384. - М.: ОАО «ЦПП», 2011.

3. Травуш В.И., Конин Д.В., Крылов А.С., Каприелов С.С., Чилин И.А. Экспериментальные исследования сталежелезобетонных конструкций, работающих на изгиб. // Строительство $u$ реконструкиия, 2017, №4(72), с. 63-71.

4. EN 1994-1-1 (2004) (English): Eurocode 4: Design of composite steel and concrete structures - Part 1-1: General rules and rules for buildings [Authority: The European Union Per Regulation 305/2011, Directive 98/34/EC, Directive 2004/18/EC].

5. СП 266.1325800.2016 Конструкции сталежелезобетонные. Правила проектирования. - М.: Кодекс, 2017.

6. СП 63.13330.2012 Бетонные и железобетонные конструкции. Актуализированная редакция СНиП 52-01-2003. - М.: Кодекс, 2011.

7. Стандарт организации СТО АРСС 11251254.001-018-4 Руководство по проектированию сталежелезобетонных конструкций (в развитие СП 266.1325800.2016 «Конструкции сталежелезобетонные. Правила проектирования»). - М., 2018.

8. Травуш В.И., Каприелов С.С., Конин Д.В., Крылов А.С., Кашеварова Г.Г., Чилин И.А. Определение несущей способности на сдвиг контактной поверхности «сталь - бетон» в сталежелезобетонных конструкциях для бетонов различной прочности на сжатие и фибробетона. // Строительство и реконструкиия, 2016, №4(66), c. 45-55.

9. Travush V.I., Konin D.V., Krylov A.S. Strength of composite steel and concrete beams of high-performance concrete. //
Magazine of Civil Engineering, 2018, No. 3(79), pp. 36-44.

Alexey S. Krylov, Researcher; Research Center of Construction, Research Institute of Building Constructions (TSNIISK) named after V. A. Koucherenko; b. 6, 2-ja Institutskaja ul., Moscow, 109428, Russia;

phone+7(499)174-79-21; e-mail: kryl07@mail.ru.

Крылов Алексей Сергеевич, научный сотрудник; Научно-исследовательский центр "Строительство», Центральный научно-исследовательский институт строительных конструкций (ЦНИИСК) имени В.А. Кучеренко; 109428, Российская Федерация, г. Москва, ул. 2-я Институтская, д. 6; тел. +7(499)174-79-21; E-mail: kryl07@mail.ru. 